\title{
Physical and milling properties of chickpea, Cicer arietinum influenced by seed characteristics
}

\author{
Ashwini Tikle ${ }^{1 *}$ and Archana Mishra ${ }^{2}$ \\ ${ }^{1}$ Department of Home Science, Govt. Maharani Laxmi Bai Girls P.G. College, Bhopal, Madhya Pradesh, India \\ ${ }^{2}$ Department of Home Science, Rani Laxmibai Girls College, Bhopal, M.P India
}

\begin{abstract}
Physical and mechanical properties of food gains is important during designing, improvement and optimization for separation and cleaning. More than 190 varieties of chickpea belonging to both kabuli and desi types have been released in India on the basis of yield and disease reaction, ignoring the miller's and traders' preferred processing traits. There is dearth of information about milling performance of chickpea varieties cultivated in India. The objective of this work was comparing some physical properties of two kabuli and two desi varieties of chickpea seeds (Kripa, RVKG 101 and JAKI 9218, JG 130). Although kabuli type chickpea varieties are mostly consumed as whole seed, yet they were included in the study for comparing their milling potential with desi types. Milling quality of the seeds was also found to be affected by their physical properties and varietal differences were also observed. The maximum values of seed weight, volume and bulk density among the varieties were observed in kabuli type variety Kripa. The kabuli varieties, exhibited better dal recovery (70.69 $-71.04 \%)$ than desi (66.12- 66.38\%) along with lesser husk content (5.32-5.77\%) than desi (8-47-9.74\%) due to their thinner seed coat. The dal recovery was positively correlated with 100 -seed weight and volume but negatively correlated with true density. Dal recovery among desi varieties can be improved by reducing seed coat thickness.
\end{abstract}

KEY WORDS: PHYSICAL PROPERTIES; MILLING CHARACTERISTICS; BULK DENSITY

\section{INTRODUCTION}

Food legumes including beans and chickpea are important food crops because of their nutritional quality for supplementation of protein in vegetarian diet. They are rich sources of complex carbohydrates, proteins, vitamins

\section{ARTICLE INFORMATION:}

*Corresponding Author: chimuashwini8@gmail.com Received $21^{\text {st }}$ Jan, 2018

Accepted after revision $11^{\text {th }}$ March, 2018

BBRC Print ISSN: 0974-6455

Online ISSN: 2321-4007 CODEN: USA BBRCBA

$\therefore$ Thomson Reuters ISI ESC / Clarivate Analytics USA and Crossref Indexed Journal

NAAS Journal Score 2017: 4.38 SJIF 2017: 4.196

- A Society of Science and Nature Publication, Bhopal India 2018. All rights reserved.

Online Contents Available at: http//www.bbrc.in/

DOI: $10.21786 / \mathrm{bbrc} / 11.1 / 17$ and minerals (Wang et al., 2010). Legumes have been considered a rich source of protein throughout the world and contain approximately three times more proteins than cereals. Chickpea (Cicer arientum L.) is considered as the fifth valuable food legume in terms of worldwide economical standpoint. It has been used for the preparation 
of various traditional foods such as ingredient in bakery products, imitation milk, infant food formulations and meat products (Ravi and Suvendu, 2004, Ashok Kumar et al, 2015; Jukanti, et al 2012). Different traditional oriental foods are prepared using chickpea flour both at household and industrial levels. Dried legume seeds generally promote slow and moderate postprandial blood glucose increase. They are also a source of high-quality protein and have been known as "a poor man's meat" (Isabel and Garmen, 2003; Rincon et al., 1998; Taylor et al, 2016; Fabri et al, 2016; Carmo et al, 2017).

India is the largest producer (22.95 m tonnes), consumer (22.49 m tonnes) and importer (4.67 m tonnes) of pulses in the world (DES, 2017-18). It is also the largest pulses processor owing to poor pulse processing facilities in the major exporting countries like Pakistan (21.6\%), UAE (10.6\%), Algeria (11.6\%) and Saudi Arab (9.5\%) (DACEFW 2017). Chickpea is the most important pulse crop in India accounting for nearly 40\% (9.33 m tonnes) of the total pulse production (22.95 m tonnes) and 64\% of total pulse export during 2017-18 (DACEFW, 2017).

It is a good source of carbohydrates and protein which accounts for about $80 \%$ of the total dry seed mass (Geervani 1991, Chibbar et al. 2010) and constitutes an important component of diet of largely vegetarian Indian masses. Chickpea seed has high digestible protein and complex carbohydrate with low glycemic index and is relatively free from anti-nutritional factors (Muzquiz and Wood 2007, Wood and Grusak 2007; Riberro et al, 2017).

Chickpea protein complements cereal based diet with several essential amino acids.

Information on physical properties of byproducts is needed in designing and adjustment of agricultural machineries (Ghamari, 2012; Alexander et al 2017). The geometric properties such as size and shape are the most important physical properties considered during the separation and cleaning of grains (Nalbandi et al., 2010; Meng et al 2010; Wood et al, 2017). In view of this, several studies have been conducted on the physical prop- erties such as size, weight, volume, bulk density, true density of different crops. Because of varietal variability in chickpea seeds, understanding of physical properties of different varieties is necessary. Milling characteristics are important for dhal processing units where whole dhal recovery is an important factor for dhal processors. The dhal processing of legumes are mainly influenced by the size of the grain, the husk, the adherence of the husk to the seed and cotyledon texture properties. When there is a strong adherence of seed coat to the cotyledons, it hinders in the milling and whole dhal recovery is affected. The objective of this work was to study some physical properties of four varieties of chickpea seeds (Fig.1) to develop appropriate technologies in designing and adjustment of machines used during harvesting, separating, cleaning, handling and storing of them.

\section{MATERIAL AND METHODS}

Four released varieties of chickpea (kabuli and desi) were procured from Department of Plant Breeding and Genetics, R.A.K. College of Agriculture, Sehore, Madhya Pradesh. Grains of all the varieties were thoroughly cleaned and stored in airtight containers before analyzing.: Bengal Gram or Gram- in Hindi Chana are the local names and scientifically called chickpea has the botanical name Cicer arietinum (L.). Broadly, chickpea is categorized into two type- Desi and kabuli. Desi chana has dark seed, rough (puckered) seed coat while kabuli type is smooth and light coloured seed coat. Adherence of seed coat to the cotyledons in desi type is tight while it is loose in kabuli. Kabuli chickpeas are mainly used for table purpose as a whole grain while desi type is mainly used for making dhal. The scientific names of both type is same-Cicer arietinum.

All the observations were taken in triplicates and mean values are used for further analysis. The various physical properties like 100-grain weight, 100-grain volume and bulk density were determined by standard method and true

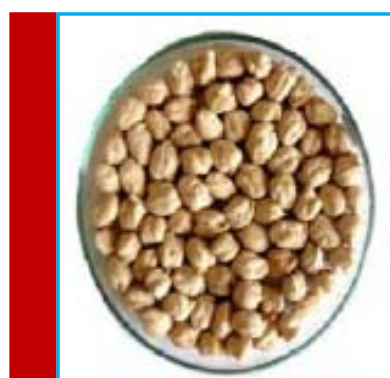

KRIPA (Phule G0517)

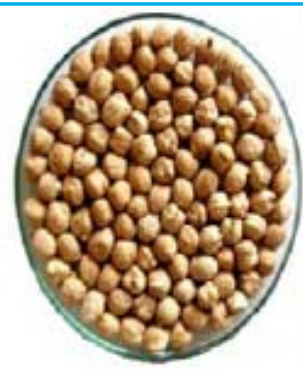

RVKG-101

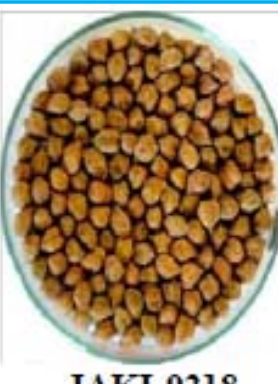

JAKI-9218

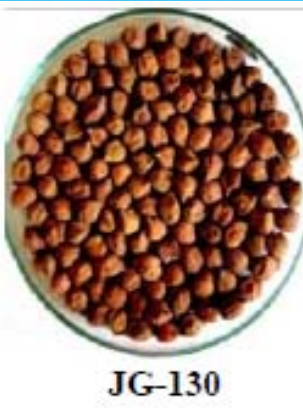

JG-130

FIGURE 1. Pictorial view of grains of chickpea (Cicer arietinum (L.)-Kabuli and Cicer arietinum (L.)-Desi) varieties 


\begin{tabular}{|l|l|l|l|l|}
\hline \multicolumn{6}{|l|}{ Table 1. Physical characteristics of seeds of gram varieties } \\
\hline Variety & $\begin{array}{l}100 \text { Seed } \\
\text { weight }(\mathrm{g})\end{array}$ & $\begin{array}{l}\text { 100 Seed } \\
\text { volume }(\mathrm{ml})\end{array}$ & $\begin{array}{l}\text { Bulk density } \\
(\mathrm{g} / \mathrm{ml})\end{array}$ & $\begin{array}{l}\text { True density } \\
(\mathrm{g} / \mathrm{ml})\end{array}$ \\
\hline Kripa & 56.74 & 70.67 & 0.80 & 0.83 \\
\hline RVKG 101 & 45.88 & 61.67 & 0.74 & 0.80 \\
\hline JAKI 9218 & 24.79 & 32.67 & 0.75 & 1.33 \\
\hline JG 130 & 25.62 & 33.33 & 0.76 & 0.87 \\
\hline Mean & 38.26 & 49.58 & 0.77 & 0.96 \\
\hline SEm & 0.45 & 1.24 & 0.019 & 0.022 \\
\hline C.D.5\% & 1.57 & 4.31 & 0.066 & 0.077 \\
\hline
\end{tabular}

density by Bhattacharaya et al., (1977). One kg of grain was milled in CFTRI Dhal making machine and the splits, broken grains and husk were weighed separately to estimate the Dhal recovery of grains (Agrawal and Singh 2003).

Three measurements were taken on each analysis and the results were expressed as the mean of those values \pm standard deviation. Significance was tested using the Duncan's Multiple Range Test at 5\% level of probability.

\section{RESULTS AND DISCUSSION}

Seed weight, seed volume, bulk density and true density characteristics differed significantly among the varieties except bulk density (Table 1 and Fig. 2). 100 seed weight ranged from 24.79 to 56.74 g; seed volume from 32.67 to $70.67 \mathrm{ml}$ and both physical properties were observed highest in kabuli gram variety Kripa (Phule G-0517). All the varieties under evaluation have more or less parallel bulk density ranging from 0.75 to $0.80 \mathrm{ml}$. Highest true density was observed in desi variety of gram i.e. JAKI $9218(1.33 \mathrm{~g} / \mathrm{ml})$ followed by JG $130(0.87 \mathrm{~g} /$ $\mathrm{ml})$ and least in kabuli gram variety RVKG 101 (0.80 $\mathrm{g} / \mathrm{ml}$ ). It revealed that the particles of the desi variety of gram have been densely packed. Agrawal \& Singh (2003) reported that 100 seed weight varied from 23.12 to $25.15 \mathrm{~g}$ in chickpea varieties.

\section{MILLING CHARACTERISTICS}

Dhal recovery ranged from 66.12-71.04 per cent; Kripa registered high value (71.04\%) and least was found in

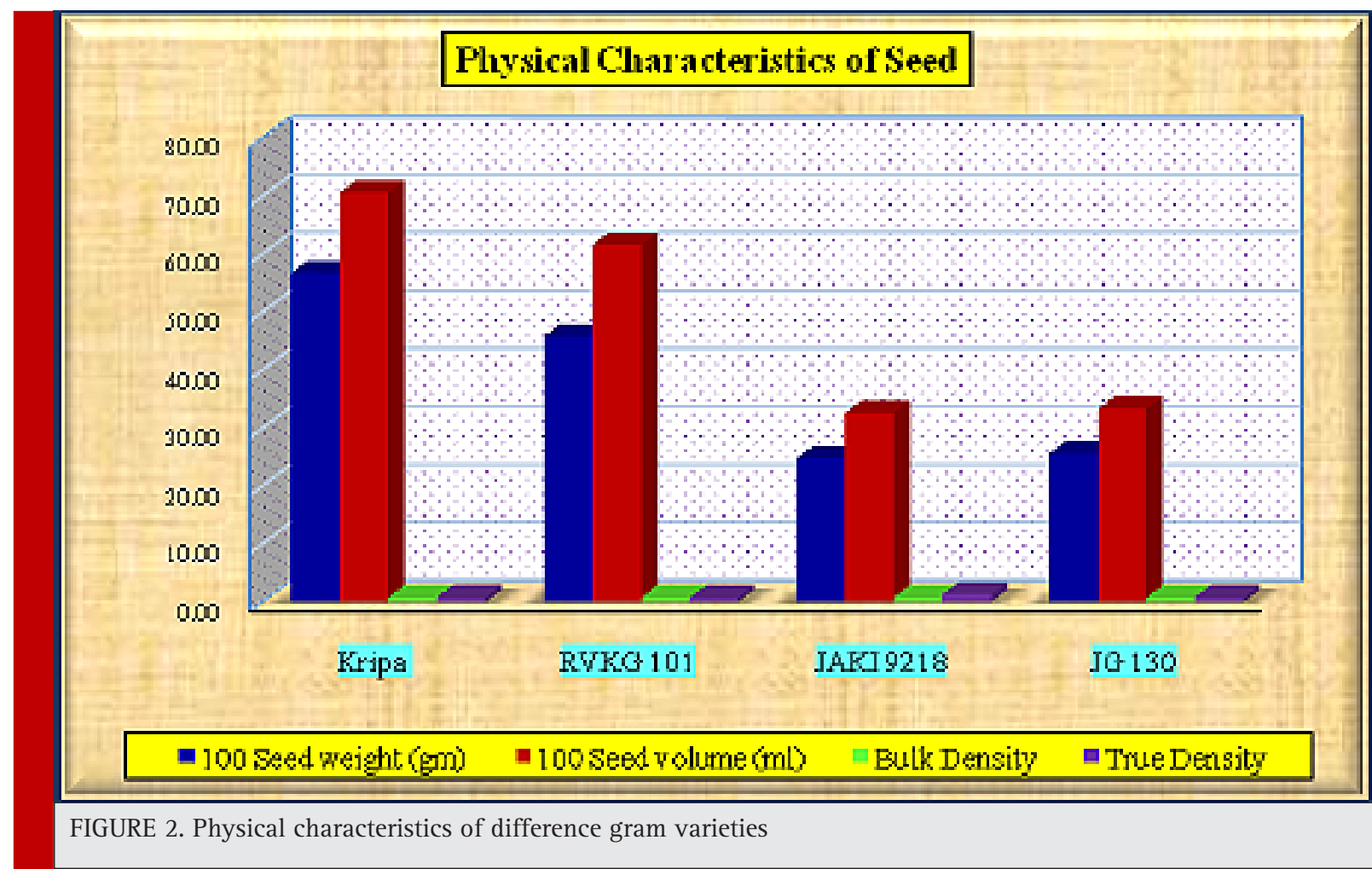




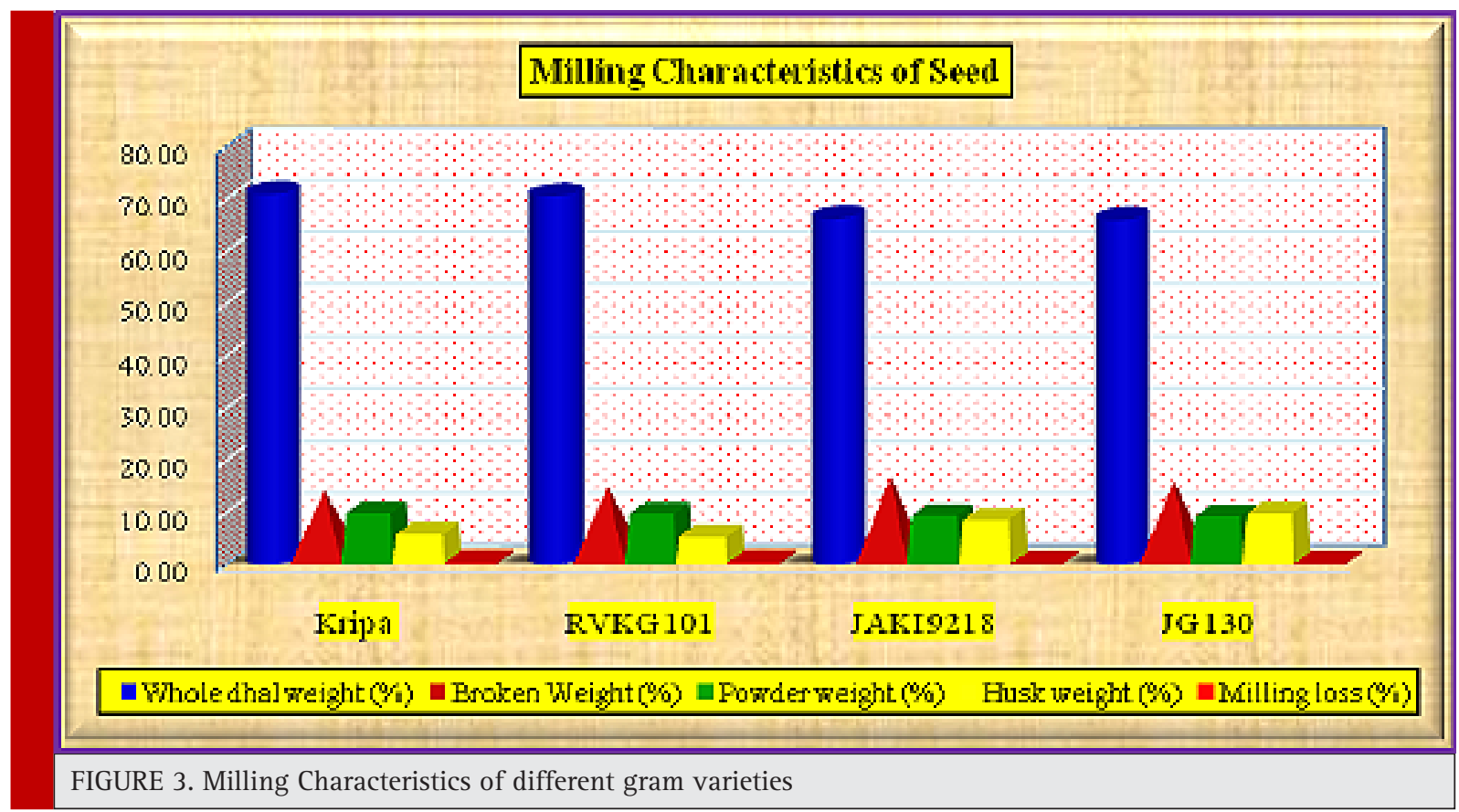

\begin{tabular}{|l|l|l|l|l|l|}
\hline \multicolumn{5}{|l}{$\begin{array}{l}\text { Table 2. Means of Milling Characters and cooking quality of dhal of gram } \\
\text { varieties }\end{array}$} \\
\hline \multirow{2}{*}{ Variety } & \multicolumn{4}{|c|}{ Milling characters (Percent recovery- Weight basis) } \\
\cline { 2 - 6 } & Whole Dal & Broken Dal & Powder & Husk & Milling loss \\
\hline Kripa & 71.04 & 13.07 & 9.77 & 5.77 & 0.36 \\
\hline RVKG 101 & 70.69 & 13.93 & 9.66 & 5.32 & 0.40 \\
\hline JAKI 9218 & 66.38 & 15.72 & 9.32 & 8.47 & 0.11 \\
\hline JG 130 & 66.12 & 14.83 & 9.14 & 9.74 & 0.17 \\
\hline Mean & 68.56 & 14.39 & 9.47 & 7.32 & 0.26 \\
\hline SEm & 0.442 & 0.319 & 0.115 & 0.208 & 0.049 \\
\hline C.D.5\% & 1.530 & 1.106 & 0.399 & 0.720 & 0.172 \\
\hline
\end{tabular}

JG $130(66.12 \%)$ as kabuli gram have thinner testa as compared to desi and its adherence to cotyledons is also loose. Therefore, removal of testa becomes easier in kabuli gram. The brokens and powder varied from 13.0715.72 and 9.14-9.77 per cent respectively. Amount of husk is supposed to be proportional to the thickness and mass of husk over the cotyledon. Therefore, kabuli gram varieties have lower husk recovery than desi type. The husk varied from 5.32-9.74 per cent whereas JG 130 (9.74\%) recorded higher value and RVKG 101 (5.32\%)

\begin{tabular}{|l|l|l|l|l|l|l|l|}
\hline \multicolumn{6}{|c|}{ Table 3. Correlations of physical Et milling characteristics in kabuli and desi gram varieties. } \\
\hline & $\begin{array}{l}\text { 100 Seed } \\
\text { weight (g) }\end{array}$ & $\begin{array}{l}\text { 100 Seed } \\
\text { volume }\end{array}$ & $\begin{array}{l}\text { Bulk } \\
\text { density }\end{array}$ & $\begin{array}{l}\text { True } \\
\text { density }\end{array}$ & $\begin{array}{l}\text { Whole } \\
\text { Dal (\%) }\end{array}$ & $\begin{array}{l}\text { Broken } \\
\text { Dal (\%) }\end{array}$ & $\begin{array}{l}\text { Powder } \\
(\%)\end{array}$ \\
\hline 100 Seed Volume & 0.995 & & & & & & \\
\hline Bulk density & $0.582^{*}$ & $0.501^{*}$ & & & & & \\
\hline True density & $-0.634^{*}$ & $-0.648^{*}$ & -0.288 & & & & \\
\hline Whole Dal & $0.971^{* *}$ & $0.989^{* *}$ & 0.372 & $-0.624^{*}$ & & & \\
\hline Broken Dal & $-0.954^{* * *}$ & $-0.943^{* *}$ & $-0.631^{*}$ & $0.814^{* *}$ & $-0.899^{* * *}$ & & \\
\hline Powder & $0.955^{* *}$ & $0.964^{* *}$ & 0.419 & -0.433 & $0.972^{* *}$ & $-0.825^{* *}$ & \\
\hline Milling loss & $0.909^{* * *}$ & $0.941^{* *}$ & 0.242 & $-0.779^{*}$ & $0.963^{* * *}$ & $-0.897^{* * *}$ & $0.874^{* * *}$ \\
\hline
\end{tabular}


had least one. Milling loss ranged from 0.11-0.40 per cent, RVKG 101 recording higher $(0.40 \%)$ values and least was found in JAKI 9218 (0.11\%). There was significant difference in all the milling characteristics.

Bindu Et Kasturiba (2017) reported that husk varied between 8.45-10.07 per cent and dhal recovery between 76.55-78.55 per cent. Less than 10 per cent of the grains were collected as brokens which is unavoidable in milling of pulses. In general bold-seeded varieties produced slightly higher per cent of powder than small-seeded varieties. Other reported a dal yield ranging from 83.1$87.8 \%$ in kabuli types and 61.3-82.6\% in desi chickpea types (Shrivastava et. al., 2017).

Correlation of Physical and Milling Characteristics

The whole dhal recovery is higher where 100 seed weight and 100 seed volume is more but it also caused more milling loss as well as more powder. It was also evidenced from positive correlation of 100 seed weight with powder and milling loss. It is also observed that true density has negative correlation with whole dhal recovery, powder and milling loss signifying the vice-versa relationship amongst them while, broken dhal is positively correlated with the true density (Table 3). Therefore they should have been the balanced of 100 seed weight and true density to minimize the milling losses, broken dhal to recover maximum whole dhal. 100 seed weight and true density also contributed to affect the milling properties of chickpea (Deshpande et al., 1993, Nimbalkar 2000; Ravi and Harte, 2017; Alexander et al, 2017).

\section{CONCLUSION}

Kabuli gram (Kripa) had significantly higher seed weight of $56.74 \pm 1.57$ followed by RVKG $101(45.90 \pm 1.57)$. Desi gram had average 100 seed weight, 100 seed volume $(70.67 \mathrm{ml})$, while, JAKI 9218 occupies only 32.63 $\mathrm{ml}$ volume. Among the varieties used in the study kabuli gram variety Kripa had the highest dhal recovery of 71.04\% in overall kabuli gram have higher dhal recovery than desi gram. The milling recovery of whole dhal was also found higher in kabuli gram varieties than that of desi ones, most preferable by the millers.

\section{REFERENCES}

Agrawal K and Singh G (2003). Physico-chemical and milling quality of some improved varieties of chickpea (Cicer arietinum). Journal of Food Science and Technology 40 (4): 439442.

Aleksandar Yovchev; Andrea Stone; Shannon Hood-Niefer and Michael Nickerson (2017) Influence of the extrusion parameters on the physical properties of chickpea and barley extrudates. Food Science and Biotechnology 26 (2):393-399.
Ashok Kumar K, Diapari M, Jha AB, Tar'an B, Arganosa G, Warkentin TD (2015) Genetic diversity of nutritionally important carotenoids in 94 pea and 121 chickpea accessions. Journal of Food Composition and Analysis 43, 49-60.

Bhattacharya, K.R.; Sowbhagya, C.M.; and Y.M., Indhudharaswami, (1977). Some physical properties of paddy and their inter-relationship. J. Sci. Food Agric. 23:171-174.

Carmo Serrano; Bruna Carbas; Ana Castanho; Andreia Soares; Maria Carlota Vaz Patto and Carla Brite (2017) Characterization of nutritional quality traits of a chickpea (Cicer arietinum) germplasm collection exploited in chickpea breeding in Europe. Crop and Pasture Science 68(10-11): 1031-1040.

Chibbar R N, Ambigaipalan P and Hoover R. (2010). Molecular diversity in pulse seed starch and complex carbohydrates and its role in human nutrition and health. Cereal Chemistry 87: 342-352.

DACEFW 2017. Commodity profile of pulses-Nov., 2017. Department of Agriculture, Co-operation and Farmers Welfare, Ministry of Agriculture and Farmers Welfare, Government of India.

Deshpande, S. D., S. Bal. and T. P. Ojha (1993) Physical properties of Soya bean. Journal of Agricultural Engineering Research 56: 89-98.

Directorate of Economics and Statistics (2017-18), Ministry of Agriculture \&t Farmers Welfare, Govt. of India, New Delhi.

Fabbri ADT; Schacht R.W. and Crosby, G.A. (2016) Evaluation of resistant starch content of cooked black beans, pinto beans, and chickpeas. NFS Journal 3, 8-12.

Geervani, P. (1991). Utilization of chickpea in India and scope for novel and alternative uses. (In) Proceedings of a Consultants Meeting, 27-30 March 1989, pp 47-54, Patancheru, ICRISAT.

Ghamari, S. (2012). Classification of chickpea seeds using supervised and unsupervised artificial neural networks. Afr. J. Agr. Res.7: 3193-3201.

Isabel, G. and Garmen, V.G. (2003). Chickpea flour ingredient slows glycemic response to pasta in healthy volunteers. Food Chemistry 81: 511-515.

Jukanti, A.K.; Gaur PM, Gowda CLL, Chibbar RN (2012) Nutritional quality and health benefits of chickpea (Cicer arietinum L.): a review. British Journal of Nutrition 108, S11-S26. vemore Nkhata Malunga,;Shimrit Dadon Bar-El,; Eli Zinal,; Zipi Berkovich, Shahal Abbo and Ram Reifen (2014) The potential use of chickpeas in development of infant follow-on formula. Nutrition Journal413:8-10.

Meng X, Threinen D, Hansen M, Driedger D. (2010) Effects of extrusion conditions on system parameters and physical properties of a chickpea flour-based snack. Food Res. Int. 43: 650-658.

Muzquiz M and Wood J A. (2007). Antinutritional factors. In: Chickpea Breeding and Management, pp 143-166.

Nalbandi, H., Seiiedlou, S., Ghassemzadeh, H.R., (2010). Aerodynamic properties of Turgenialatifolia seeds and wheat kernels. Int. Agrophys. 24: 57-61. 
Nimbalkar, R.D. (2000). Genetic variability and heritability studies and scope for improvement in chickpea. J. Mah. Agrc. Uni.25:109-110.

Ravi, Ramasamy \&t Harte, Janice. (2009). Milling and physicochemical properties of chickpea (Cicer arietinum L.) varieties. Journal of the Science of Food and Agriculture 89(2):258 266 .

Ravi, R. and Suvendu, B. (2004). Flow behavior of chickpea (Cicer arietinum L.) flour dispersions: effect of additives. Journal Food Engineering 65: 619-624.

Ribeiro I.C; Leclercq, C.C.; Simões, N.; Toureiro, A.; Duarte, I.; Freire, J.B.; Chaves, M.M.; Renaut, J. and , Pinheiro C5. (2017) Identification of chickpea seed proteins resistant to simulated in vitro human digestion. J Proteomics. 2017 3;169:143-152.

Rincon, F., Mart Inez, B. and Ibanez, V. (1998). Proximate composition and anti-nutritive substances in chickpea (Cicer arietinum L) as effected by the biotype factor. Journal Science and Food Agriculture 78: 382-388.
Srivastava A.K., Dixit, G.P. and Kumar N. (2017). Milling properties of desi and kabuli chickpea (Cicer arietinum L.) varieties released in India. Indian Journal of Agricultural Sciences 87 (10): 1350-1357.

Taylor C. Wallace, Robert Murray, and Kathleen M. Zelman (2016) The Nutritional Value and Health Benefits of Chickpeas and Hummus. Nutrients 18 (2): 766-770.

Wang, N., Hatcher, D. W., Tyler., R. T. Toews, R. and Gawalko, E.J. (2010). Effect of cooking on the composition of beans (Phaseolus vulgaris L.) and chickpeas (Cicer arietinum L.). Food Research International 43: 589-594.

Wood J A and Grusak M A. (2007). Nutritional value of chickpea. (In) Chickpea Breeding and Management, pp 101-42.

Wood, J.A., Knights, E.J., Campbell, G.M. and Choct, M. (2014) Differences between easy- and difficult-to-mill chickpea (Cicer arietinum L.) genotypes. Part I: Broad chemical composition. Journal of the Science of Food and Agriculture 94: 1437-1445. 